\title{
New data about Matonia braunii (Göppert) Harris from the Early Jurassic of Poland and its ecology
}

\author{
Maria BARBACKA ${ }^{1,2, *}$, Grzegorz PACYNA ${ }^{3}$, Grzegorz PIEŃKOWSKI ${ }^{4}$ and Jadwiga ZIAJA ${ }^{1}$ \\ 1 Polish Academy of Sciences, W. Szafer Institute of Botany, Lubicz 46, 31-512 Kraków, Poland \\ 2 Hungarian Natural History Museum, Department of Botany, 1476 Budapest, P.O. Box 222, Hungary \\ 3 Jagiellonian University, Institute of Botany, Department of Palaeobotany and Palaeoherbarium, Lubicz 46, \\ 31-512 Kraków, Poland \\ 4 Polish Geological Institute - National Research Institute, Rakowiecka 4, 00-975 Warszawa, Poland
}

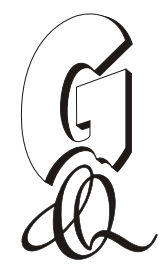

Barbacka, M., Pacyna, G., Pieńkowski, G., Ziaja, J., 2016. New data about Matonia braunii (Göppert) Harris from the Early Jurassic of Poland and its ecology. Geological Quarterly, 60 (4): 857-868, doi: 10.7306/gq.1322

\begin{abstract}
Fern remains of matoniacean affinity were found in the Lower Hettangian strata of lacustrine/backswamp origin from the Niekłań PGI 1 borehole (central Poland, Holy Cross Mts.). The preserved fragments have been identified as Matonia braunii (Göppert, 1841) Harris, 1980. The remains suggest a rather small, low-growth plant with palmately compound fronds. The sori contain at least 5 sporangia preserved with well-developed annuli. The spores are triangular, trilete and kyrtomate, with a thin and smooth surface corresponding with dispersed Dictyophyllidites mortoni (de Jersey, 1959) Playford et Dettmann, 1965. Based on the gross morphology of sterile and fertile pinnae, suggestions made by Harris (1980) on the synonymy of Phlebopteris braunii (Göppert, 1841) Hirmer et Hörhammer, 1936 with P. muensteri Schenk, 1867 (Hirmer and Hörhammer, 1936) and their referral to Matonia braunii is proved and confirmed in this paper. The fern occurs in strata indicating a warm and humid climate and approaching transgression resulting in a high water table and the enhanced accumulation of organic matter.
\end{abstract}

Key words: Poland, Holy Cross Mts., Hettangian, Matonia.

\section{INTRODUCTION}

During the Mesozoic, diversified ferns constituted a prominent element in the land vegetation of the time (Van Konijnenburg-van Cittert, 2002; Wang, 2002). Families such as Matoniaceae, Dipteridaceae, Schizaeaceae, Gleicheniaceae, Hymenophyllaceae, Osmundaceae, Marattiaceae and Cyatheaceae flourished in Triassic and Jurassic times (Cleal, 1993). Today, these fern families are mainly restricted to tropical regions and are represented by a few taxa only (Seward 1899; Berry, 1919; Camus, 1990; Iwasuki, 1990; Kramer, 1990; Skog, 2001; Rothwell and Stockey, 2008; Taylor et al., 2009). Today's dominant fern families like Polypodiaceae and Aspleniaceae (broadly conceived) originated during the Cretaceous (Schneider et al., 2004; Smith et al., 2006; Christenhusz and Chase, 2014). In the Early Jurassic, ferns were widespread in many European localities (Barbacka et al., 2014b) especially in fluvial-deltaic coal-generating floras of the kind encountered in Sweden, Hun-

* Corresponding author, e-mail: maria.barbacka@gmail.com

Received: September 12, 2016; accepted: October 26, 2016; first published online: November 10, 2016 gary and Romania (Lundblad, 1950; Tralau, 1965; Popa, 1997; Barbacka, 2011; Barbacka et al., 2014b, 2015).

Matoniaceae had their widest distribution during the Mesozoic, with records ranging from Greenland to Antarctica (Schenk, 1867; Seward, 1900; Berry, 1919; Harris, 1931, 1961, 1980; Arnold, 1956; Ash, 1969, 1972, 1991, 2001; Rushforth, 1970; Appert, 1973; Schweitzer, 1978; Ash et al., 1982; Czier, 1994; Skog and Litwin, 1995; Givulescu and Popa, 1998; Wang and Mei, 1999; Klavins et al., 2004; Mirzaie Ataabadi et al., 2005; Bartiromo et al., 2006; Nagalingum and Cantrill, 2006; Schmidt and Dörfelt, 2007; Schweitzer et al., 2009; Kvaček and Dašková, 2010; Naugolnykh and Pronin, 2015). About ten fossil genera of this family have been described from the Mesozoic based on their foliage, and a similar number based on petrified rhizomes and petioles (Hirmer and Hörhammer, 1936; Skog, 1988; Tidwell and Skog, 1992; Van Konijnenburg-van Cittert, 1993; Tidwell and Ash, 1994). Matoniacean fronds are palmately compound or pendulous, with pinnate, or more rarely bipinnate, pinnae. Sporangia are always arranged in sori (in a ring around the receptacle), often with peltate indusium arising from the sorus centre. This is regarded as one of the diagnostic features of the family (Brown in Wallich, 1830; Presl, 1848; Kramer, 1990).

Matoniaceae are represented in Polish Lower and Middle Jurassic floras by the genera Phlebopteris and Matonidium (Raciborski, 1891, 1892, 1894; Makarewiczówna, 1928; Rey- 
manówna, 1963; Barbacka et al., 2010, 2014a). According to the latest review of Polish Lower Jurassic floras, which was undertaken by Pacyna (2013), Phlebopteris angustiloba (Presl in Sternberg, 1838) Hirmer and Hörhammer 1936 is known from four localities in the Holy Cross Mts. (Odroważ, Huta, Gromadzice and Chmielów), P. elegans (Presl in Sternberg, 1838) Gothan and Weyland, 1954 from the Holy Cross Mts. (Gromadzice, Szewna, Chlewiska, Dźwiertnia, Jędrzejów and Chmielów) and also from Upper Silesia (Siewierz and Zawiercie), and P. muensteri Schenk, 1867 (Hirmer and Hörhammer, 1936) from the Holy Cross Mts. (Dźwiertnia and Chmielów) as well as Ciechocinek in the Kuyavian-Pomeranian region (Barbacka et al., 2014a). Two species, $P$. elegans and $P$. muensteri were reported from Dźwiertnia, which is located near Niekłań. Of these, according to Pacyna (2013) $P$. elegans should be referred to $P$. braunii (Göppert, 1841) Hirmer et Hörhammer, 1936.

In the Middle Jurassic flora of Grojec (Kraków region) the following species have been described: Phlebopteris angustiloba, P. muensteri (given by Raciborski, 1894) as Laccopteris mirovensis and revised by Reymanówna (1963), Microdiction woodwardii Leckenby, 1864 (Raciborski, 1894) and Laccopteris phillipsii Zigno, 1856 (Raciborski, 1894).

\section{GEOLOGICAL SETTING}

The Niekłań PGI 1 fully-cored borehole $(200$ m) located in central Poland (the northern slope of the Holy Cross Mts.) was drilled in 2010 and yielded a valuable, well-preserved core spanning the Upper Triassic - lowermost Jurassic section (Fig. 1), including a continuous profile through the Lower Hettangian section with clay mineral data reflecting important climatic changes (Pieńkowski et al., 2014; Brański, 2014).

In Early Hettangian times, the Polish Basin (along with its depocentre, which is known as the Mid-Polish Trough) was located at a northern subtropical latitude (about $40-45^{\circ} \mathrm{N}$ ). With a length of more than $700 \mathrm{~km}$, the Mid-Polish Trough, which generally runs along the Teisseyre-Tornquist Zone (TTZ) and the Trans-European Suture Zone (TESZ), is the largest of many inverted basins in western and central Europe (Ziegler, 1990). Rapid subsidence in the trough commenced in the Early Hettangian (Pieńkowski, 2004). Upper Triassic strata are represented by red and variegated mudstones (Norian-Lower Rhaetian - Zbaszynek and Wielichowo or variegated Parszów beds), covered with kaolinite-rich grey Parszów beds, reflecting a period of more humid conditions and intense chemical weathering (Pieńkowski et al., 2014). The Triassic-Jurassic boundary in the Niekłan borehole is located at a depth of $162.2 \mathrm{~m}$, at the erosional sequence boundary corresponding to the enhanced hydrological cycle and rejuvenated palaeorelief, resulting in regional erosion (Pieńkowski, 2004). The overlaying Lower Hettangian alluvial and lacustrine deposits, together with the grey Parszów beds, are assigned to the Zagaje Formation (Pieńkowski, 2004). The Zagaje Formation starts the first depositional sequence (Hettangian in age) of the epicontinental Lower Jurassic of Poland, divided into 11 parasequences (Pieńkowski, 2004), of which the lower 4 are represented in the Niekłań PIG 1 borehole (Fig. 1). From a depth of $158.9 \mathrm{~m}$ upwards, characteristic Jurassic palynomorphs (Pinuspollenites-Trachysporites assemblage) appear, including FAD (first appearance datum) of the index pollen grain Cerebropollenites thiergartii at a depth of $158 \mathrm{~m}$ (M. Hodbod, pers. comm., 2016). The strata between ca. 160 and ca. $135 \mathrm{~m}$ of the Niekłań PIG 1 borehole approximately correspond to the well-known Soltyków (also called Odrowąż) outcrop (Pieńkowski et al., 2014) exposing the lowermost
Hettangian alluvial plain deposits (Pieńkowski, 2004), which contain rich floristic remains (Reymanówna, 1992; Ziaja, 2006; Barbacka et al., 2007, 2010). The earliest Hettangian age of the outcrop is indicated by sequence stratigraphic correlation (Pieńkowski, 2004), macroflora dominated by the conifer Hirmeriella muensteri (Schenk, 1867) Jung, 1968 and Podozamites spp. (Reymanówna, 1992; Wcisło-Luraniec, 1992; Barbacka et al., 2010), the palynomorphs Classopolis torosus (Reissinger) Couper and Aratrisporites minimus Schulz (Ziaja, 1992, 2006), as well as the conchostracans Bulbilimnadia kilianorum Kozur, Weems et Lucas, 2010. The tetrapod ichnofauna of the Zagaje Formation (Hettangian) exposed at the Soltyków clay-pit shows high ichnotaxonomic diversity (Pieńkowski and Gierliński, 1987; Gierliński and Pieńkowski, 1999; Gierliński et al., 2001, 2004; Niedźwiedzki, 2011).

The Hettangian strata profile in Niekłań, like other profiles of the Zagaje Formation in the Holy Cross Mts., is of bipartite character - the alluvial part (parasequence la, Fig. 1) containing numerous sandstone layers deposited in fluvial channels is overlain by parasequence lb, dominated by much finer sediments. The boundary between parasequences la and $\mathrm{lb}$ is correlated with the Early Hettangian step-wise transgression observed in NW and central Poland (Pieńkowski, 2004; Pieńkowski et al., 2012). A rapid base-level rise had a pronounced effect on sedimentation in the continental basin located further to the south-east - alluvial deposition was rapidly replaced by fine-grained deposition and consequently, the nonmarine correlative surface (time equivalent) of the transgressive surface can be observed within continental deposits. The marine transgression in the region commenced later. This is documented by the transgressive surface at the bottom of parasequence Ic (Fig. 1 - bottom of the next Skłoby Formation). The most frequent lithofacies of the upper part of the Zagaje Formation (parasequence $\mathrm{lb}$ ) is represented by dark, organic-rich, laminated mudstones and claystones. These mudstones and claystones are dark grey to black, sometimes olive-grey, laminated or of a massive appearance, with numerous plant roots. They are usually deposited in shallow lakes or backswamps, so, as far as the lithofacies is concerned, the floodplain depositional system and lacustrine depositional system are often very similar or identical. Plant growth and pedogenic processes often obliterate primary structures. Levels with abundant small siderite concretions ("siderite sphaerulites") represent a characteristic, early diagenetic product of pedogenic processes in this permanently saturated soil. Plants represent largely typical wetland association, also of a "reed swamp" character. The shallow water tables occurring in backswamps or oxbow lakes created favourable conditions for the deposition and preservation of plant debris typical of the Gleysol type of palaeosol (Arndorff, 1993). The Gleysol type of palaeosol containing abundant plant roots and well-preserved plant fragments transformed into coal intercalations is characteristic of this depositional system.

The continuously rising sea level led to a further decrease in the delivery of clastic sediment and enhanced accumulation of peat, which can be observed in the strata just below the transgressive surface (Fig. 1, bottom of parasequence Ic). Contact between peat (or coal) and clastic sediments usually represents a considerable hiatus in clastic deposition (McCabe, 1984). For peat to form, the rate of increase in vertical accommodation space must equal the rate of accumulation of the peat, and clastics must be excluded from the environment (Bohacs and Suter, 1997). Peat accumulation probably occurred in the water-logged reducing environment of a permanently saturated palaeosol (Gleysol) where plant growth was caught up with sedimentation. The frequent coal seams at the top of the Zagaje Formation (and parasequence $\mathrm{lb}$ ) herald an approaching marine 


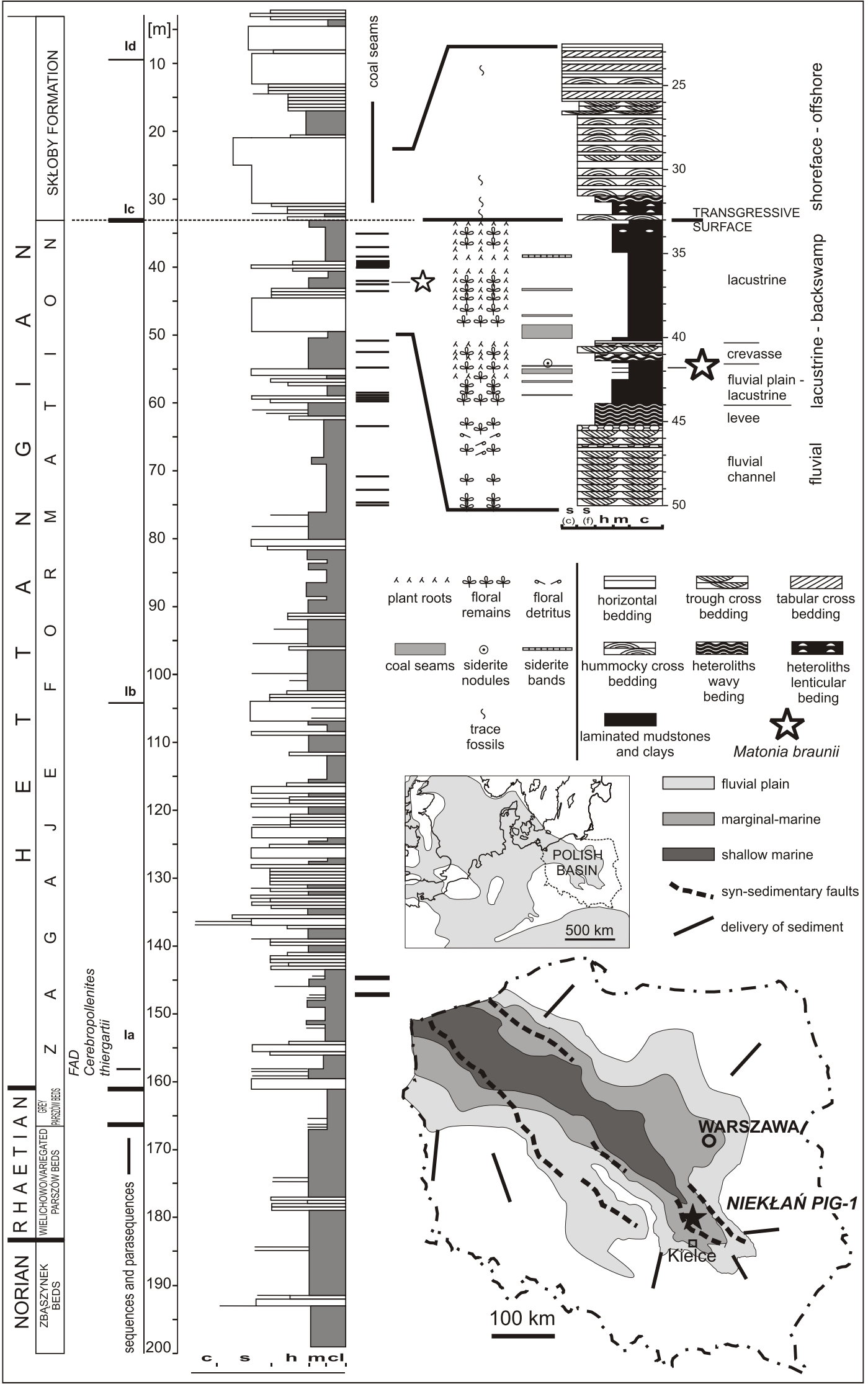

Fig. 1. Profile of the Niekłań PGI 1 borehole with position of the fern Matonia braunii (star) and its palaeogeographical and palaeoenvironmental background

Generalized profile, lithology: c - conglomerate, s - sandstone, h - heteroliths, $\mathrm{m}$ - mudstone, c - claystone; detailed profile to the right: s (c) - coarse to medium-grained sandstone, s (f) - fine-grained sandstone, $\mathrm{h}$ - heteroliths, $\mathrm{m}$ - mudstone, $\mathrm{cl}$ - claystone 
transgression. The fern was found at a depth of $41.8 \mathrm{~m}$, a metre below a thin, distal crevasse splay of a mini-delta character (the type 2 "progradational" crevasse - Aslan and Autin, 1999) in a claystone bed separating two thin coal seams (Fig. 1).

\section{MATERIAL AND METHODS}

The plant remains described in the present paper originate from a borehole $10 \mathrm{~cm}$ in diameter. The length of the frond fragments is often restricted by the diameter of the borehole. The fern is represented by 7 specimens preserved in mudstone as impressions/compressions with well-preserved, coalified matter. The largest parts of the fronds are fertile, while sterile pinnae are more fragmented. Besides these, some basal fragments of both types of pinnae are found.

Spores were obtained in situ by macerating coalified fragments of pinnules with sporangia in Schulze solution $\left(\mathrm{KClO}_{3}+\right.$ $\mathrm{HNO}_{3}$ ). These were then washed in $3 \% \mathrm{KOH}$ and centrifuged after each stage of preparation.

SEM observations were provided using a Hitachi $2360 \mathrm{~N}$ scanning electron microscope (Hitachi Co., Tokyo, Japan) for a gold coated sample imaged at $15 \mathrm{kV}$ accelerating voltage.

The specimens are stored at the Geological Museum of the Polish Geological Institute - National Research Institute in Warsaw, and labelled with numbers 80.VI.150 A-D.

Taxonomical classification is given according to Smith et al. (2006).

\section{RESULTS}

\section{SYSTEMATIC DESCRIPTION OF THE MACROREMAINS}

\section{Filicopsida}

Order: Gleicheniales Link, 1833

Family: Matoniaceae Presl, 1847

Matonia R. Brown in Wallich, 1830

Matonia braunii (Göppert, 1841) Harris, 1980

D e s cription. - Frond is palmately compound with pinnate pinnae of rather slender structure. The fertile fronds were found separately from the sterile fronds, but both are of the same type and were in close proximity in the core (Fig. 2).

The petiole of the largest preserved frond reaches $3 \mathrm{~mm}$ in width. The width of the preserved petiole in the other case is $2 \mathrm{~mm}$, widening at the palmate branching to $5 \mathrm{~mm}$. Two main basal arms arise (both rachises are 2-3 $\mathrm{mm}$ wide) from the petiole with some pinnae in between [ 3 pinnae in specimen no $80 . \mathrm{VI}$. 151C (b)]. They have 1-1.2 mm wide rachises [Fig. 2B-D, G (a)].

The basal pinnules, about $2 \times 2 \mathrm{~mm}$ large, become more elongated towards the distal part of the pinna [Fig. 2B, Ea, $F$ (a)]. The apex of the basiscopic pinnules is rather rounded [Fig. $2 \mathrm{~F}(\mathrm{a})]$, becoming subacute towards the distal end of the pinna (Fig. 3A-D).

The surface of the petioles and rachises is very finely longitudinally striated. Pinnules are opposite or subopposite. The lamina of neighbouring pinnules joins at the base, forming at the rachis a $0.2 \mathrm{~mm}$ wide $U$-shaped edge.

The largest sterile pinna fragment is $45 \mathrm{~mm}$ long. No sterile pinnule is preserved in its entirety. The longest sterile pinnule fragment is $10 \mathrm{~mm}$ long and $3 \mathrm{~mm}$ wide [Fig. 2G (b), H (b)].

Venation is mainly only evident as a distinct midrib running to the apex. Thin lateral veins are hardly visible in two sterile pinnules for a very short distance. They fork once just at the midrib (the basiscopic vein is almost at a right angle to the midrib, acroscopic vein at $45^{\circ}$ to the midrib) and at half of the pinnule width, they fork again (Fig. 4).

Fertile pinnae are preserved in larger fragments. The largest and most complete pinna fragment slightly narrows towards the apex and base. Rachis width ranges from $2 \mathrm{~mm}$ at the base of the fragment to $1 \mathrm{~mm}$ at its top. Pinnules almost perpendicular to rachis, narrow. Their length is $11-25 \mathrm{~mm}$, and their width, at $1-2 \mathrm{~mm}$, is narrower than that of the sterile pinna fragments. The distance between the pinnule bases is $2-3 \mathrm{~mm}$. The apex of the pinnules is subacute (Fig. 3A-D).

In the fertile pinnules, the veins are invisible, with the exception of the midvein running from the pinnule base to its apex. The sori are arranged alternately in two rows on both sides of the midvein, halfway between the midvein and margin (Fig. 3A, $\mathrm{E}-\mathrm{H})$. They start 2-4 $\mathrm{mm}$ from the base of the pinnule, ending at the apex. They are circular, from 317 to $840 \mu \mathrm{m}$, averaging about $550 \mu \mathrm{m}$ in diameter, and in the centre, a trace of the stalk is visible (about $130 \mu \mathrm{m}$ in diameter); the distance between neighbouring sori is about $0.3 \mathrm{~mm}$. The exact number of sporangia per sorus is unknown; the highest preserved number of annuli within one sorus is $3-5$ (Fig. 5A, B). A number of sori are covered by indusia (Fig. $3 \mathrm{H}$ ), but numerous indusia are detached and remain on the counterpart of the specimen. They are up to $1 \mathrm{~mm}$ in diameter and their margins are widely sinusoidally incised (probably a result of compression, Fig. 3E-G). Sometimes, single annuli are adhered to these detached indusia. In the centre from the inner side, a track of the stalk is also visible like on the sori (Fig. 3G). The annuli are well-developed. In major cases, only the annuli of single sporangia are observable in the sori along their whole length, while the rest of the sporangia have fallen off. They are $437-460 \mu \mathrm{m}$ long in average, the longest $851 \mu \mathrm{m}$. The width of the annulus ranges from 100.5 to $383 \mu \mathrm{m}$, averaging about $212 \mu \mathrm{m}$. The longest preserved annulus is formed by 12 cells with anticlinal walls forming ribs and periclinal walls collapsed between them. The distance between ribs ( = width of the cells measured between the medial long axes of the anticlinal walls) ranges from 14.9 to $72.9 \mu \mathrm{m}$, averaging $41 \mu \mathrm{m}$ (Fig. 5C-H).

\section{DESCRIPTION OF SPORES IN SITU}

In the macerated sporangia a total of 48 separate spores and two clusters consisting of about 20 and 40 spores (Fig. 5I) were found. Sometimes they were adhering to the sporangium cuticle shreds. Most of them are badly preserved and deformed with hardly recognisable details.

The spores are trilete and triangular in equatorial outline with rounded apices and concave or straight sides in polar view. They possess a trilete mark with elevated and labrate commissures. The kyrtome (interradial thickenings, $3-5 \mu \mathrm{m}$ across) is subparallel to the leasural radii and connected on the apices of the spores. In the equatorial view, they are plano-convex with a longitudinal fold. The exine is thin and smooth (Fig. 5J, K).

The equatorial diameter is $36-46 \mu \mathrm{m}$ ( 15 best preserved specimens measured). The polar diameter is $36-39 \mu \mathrm{m}$ (4 specimens measured). The dimensions of clusters measured in the widest parts are: $172 \times 162 \mu \mathrm{m}$ and $215 \times 215 \mu \mathrm{m}$.

The number of spores per sporangium is impossible to determine precisely because of relatively small amount of spores found in the macerated sporangia. We estimate that one cluster of spores contains about 20 or 40 spores and probably fills one sporangium. 

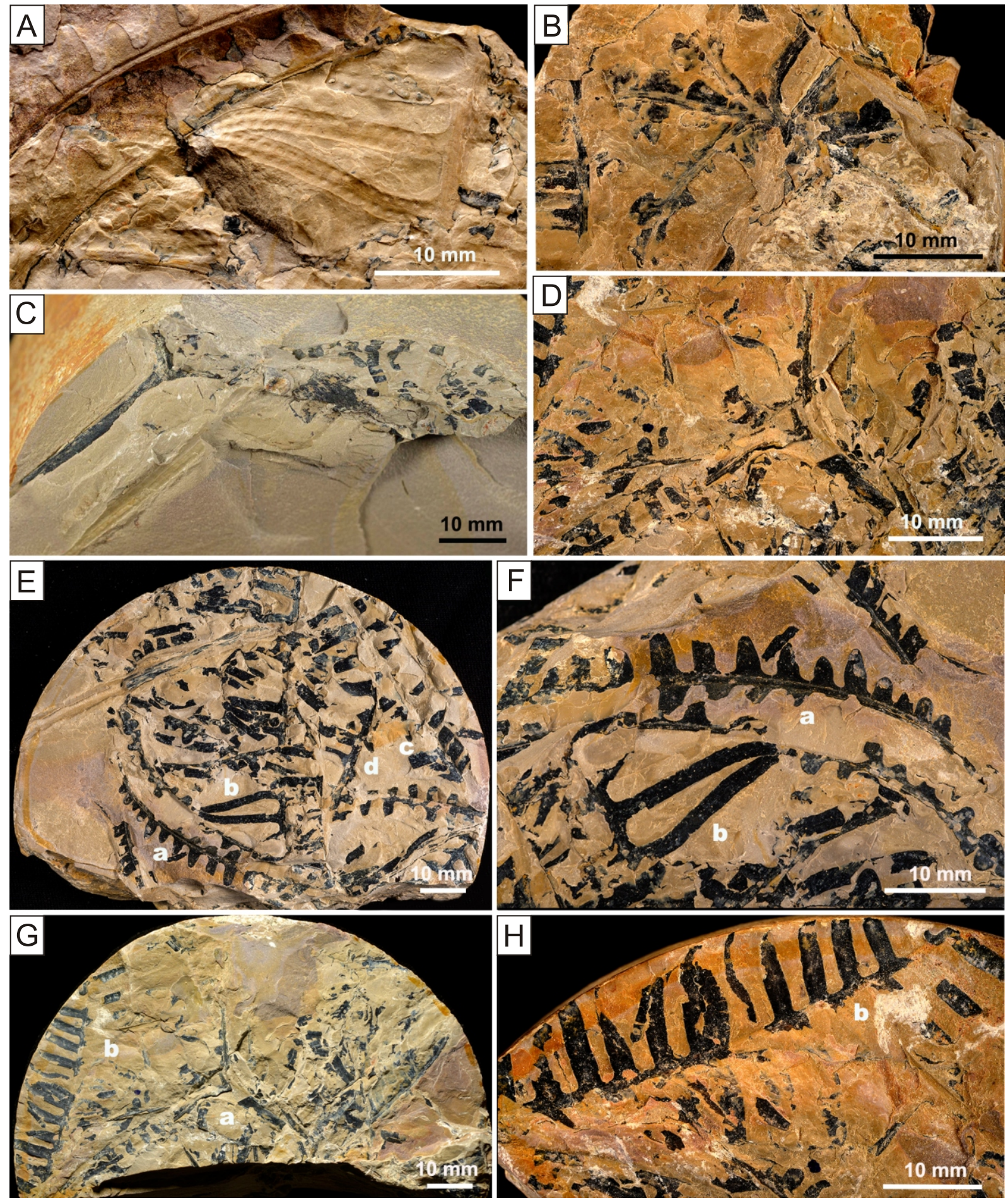

Fig. 2. Matonia braunii (Göppert) Harris

A - specimen Muz. Geol. PIG 80.VI.151C, fragments of sterile and fertile pinne; B - specimen 80 IV.151D, petiole with basal parts of pinnae; C - specimen 80.IV.151B, petiole branching into fertile pinnae; D - specimen 80.IV.151C, petiole branching; E - specimen 80.VI.151B, shape variability of pinnules: fertile pinna near base (a), in the middle part (b, d), sterile pinna (e); $\mathbf{F}-$ detail from Figure 2E, basal part with short pinnules (a), and fertile pinnules (b); G - specimen 80.VI.151C, petiole (a) associated with sterile pinnae (b); $\mathbf{H}$ - detail from Figure $2 \mathrm{G}$, sterile pinna (b)

\section{DISCUSSION}

Most of the features described above enable us to identify the fern from Niekłań as Matonia braunii. However, we are unable to be precise about the number of sporangia per sorus, their shape and the number of spores per sporangium due to the poor state of preservation of material. The fertile fronds were probably fully developed and the sporangia were ripe, which confirms the position of annuli entirely spread and visible along their full length. Usually only a single annulus is preserved in place of the sorus. To be precise, of the approximately 520 sori preserved on specimen Muz. Geol. PIG 80.VI.150A, about 140 have a single annulus, and only 6 show more than one an- 


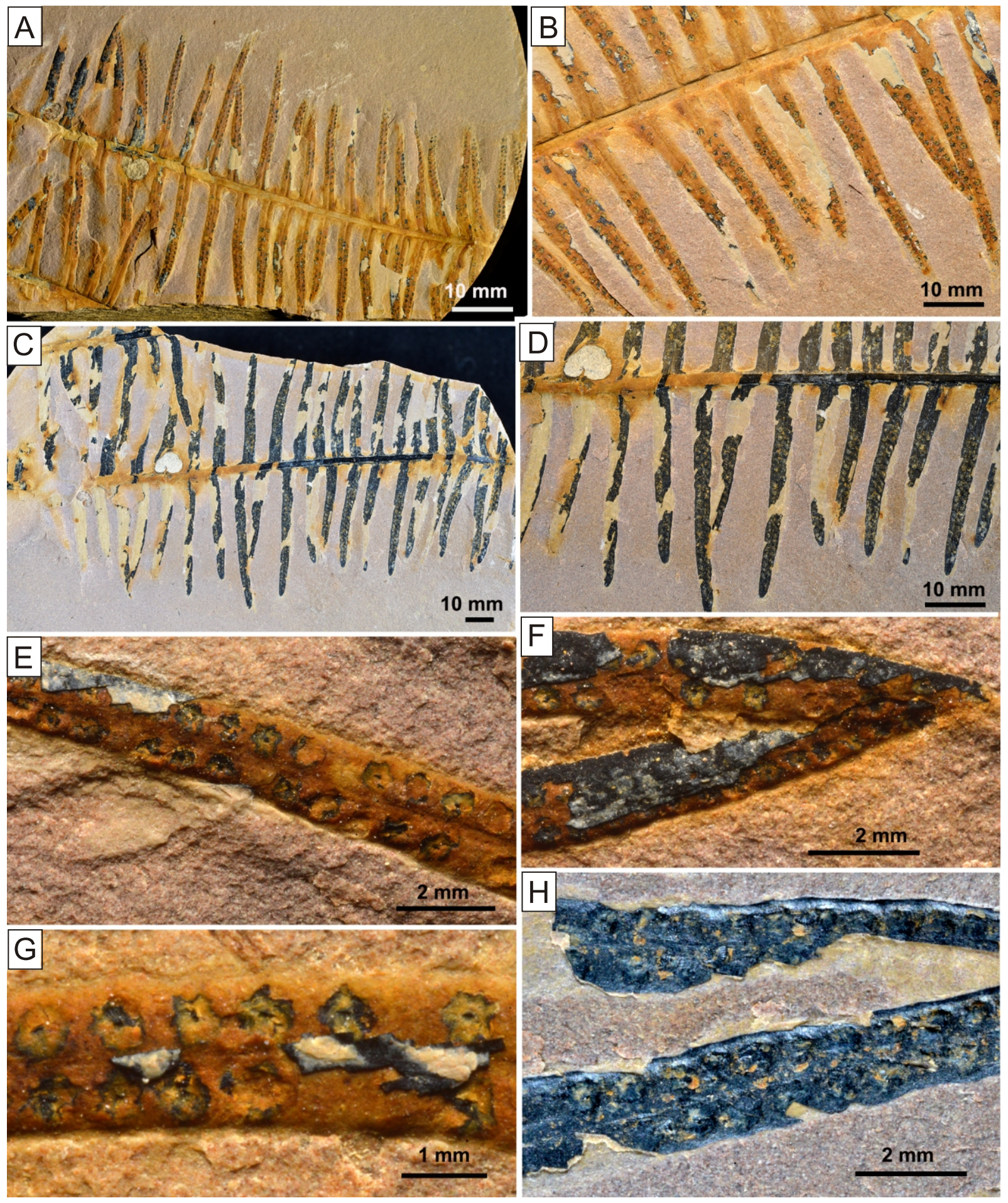

Fig. 3. Matonia braunii (Göppert) Harris

A - specimen 80.VI.150B, positive imprint; B - detail from Figure 3A, rows of sori on pinnules; C - specimen 80.VI.150A, counterpart of Figure 3A; D - detail from Figure 3C; $\mathbf{E}$ - detail from Figure 3A, indusia with stalks (in the centres); $\mathbf{F}$ - detail from Figure $3 \mathrm{~A}$, indusia; $\mathbf{G}$ - magnified detail from Figure 3A, indusia; $\mathbf{H}$ - detail from Figure $3 \mathrm{C}$, sori covered by indusia

nulus (3-5). In Matonia braunii, the usual number of sporangia per sori is $10-12$ and these are situated radially around the stalk of the indusium, as is usual in the case of Matoniaceae. The sporangia of the fern from Niekłań do not form a radial structure, but are strongly dislocated due to their state of preserva- tion. Visible annuli are also in an unusual position, not oblique, but flattened by compression.

We interpret the structures detached and visible on the specimen counterpart as sinusoidally incised coalified indusium. Their shape and circumference is a little larger than the 


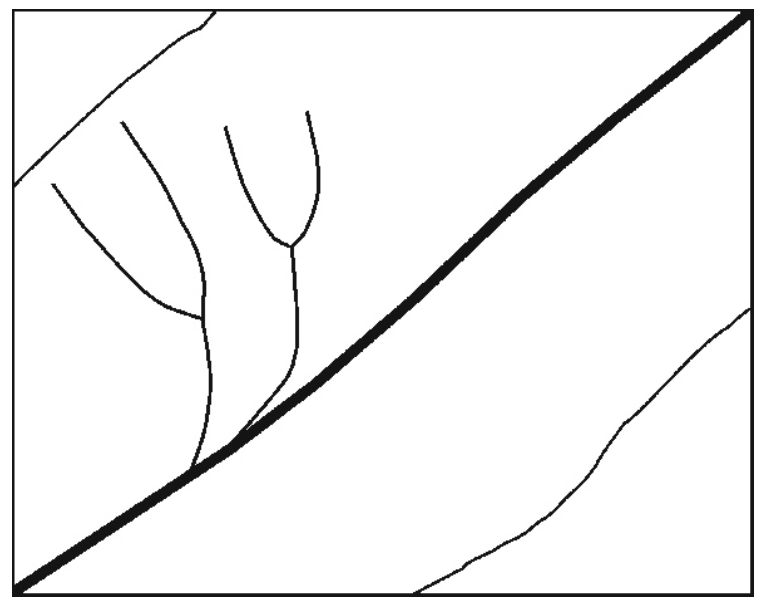

Fig. 4. Schematic drawing of pinnule venation [from specimen 80.VI.151B (e)]

circumference of the sori, and closely correspond to the indusia usually found in Matonia. The pinnule fragments which do not show these structures on the counterpart, have sori covered by a bulge of coalified matter (indusia). The detached ones are deformed by compression and incised by splitting. The presence of indusia excludes the Phlebopteris genus, suggesting Konijnenburgia Kvacek et Daskova, 2010 or Matonia. However, Konijnenburgia differs from the fern from Niekłań with regard to its venation and wedge-shaped sporangia.

Due to the preserved features of the fertile and sterile pinnules, the fern from Niekłań could be interpreted as Matonia braunii according to Harris' discussion (Harris, 1980) of this species from Yorkshire. He first discussed and confirmed the unification of sterile $P$. braunii fronds interpreted by him as a shade form, with the sterile and fertile fronds of $P$. muensteri, interpreted as a sun form, into one plant, $P$. braunii. He noticed the constant coexistence of these two species at many localities. He went on to ascribe $P$. braunii to the genus Matonia based on morphological correspondence, where only the presence of indusia (Matonia) was inconsistent. The whole Phlebopteris genus is considered to be exannulate, while the recent Matonia genus possesses indusia. Originally, Phlebopteris muensteri was described as exanullate (Schenk, 1867), but Harris (1980) recognized indusia on some specimens of this species and considered the rest of the specimens which lacked them to have lost their indusia. He noticed that in recent fertile Matonia material, the indusia can detach very easily, and come to closely resemble the apparently exanullate fronds of Phlebopteris muensteri.

Van Konijenburg-van Cittert did not fully agree with Harris (1980) on this subject. In her opinion, without proving the presence of indusia in specimens referred to Phlebopteris muensteri from classic localities in Germany and Russia, it was premature to fully accept $P$. muensteri with Matonia braunii as synonymous (apart from the material examined and described by Harris, 1980). However, fertile specimens from Niekłań, with morphology typical of $P$. muensteri, but preserved fragments with sori and counterparts with detached indusia, fully confirm Harris' statement. Van Konijenburg-van Cittert (1993) also stressed the differences in pinnule shape and venation in both species. However the close proximity in the examined core material, of specimens having pinnule morphology typical of both $P$. muensteri and $P$. braunii strongly supports Harris' assumption. According to Van Konijnenburg-van Cittert's research on matoniacean in situ spores, there are differences in spore di- ameter between $P$. muensteri and $M$. braunii. Therefore, she treated $P$. muensteri and $M$. braunii as separate species. Based on the new material from Poland, we can concur with Harris (1980) that they are conspecific

Unfortunately, the small number of specimens known from the Polish Lower and Middle Jurassic as $P$. braunii from the Holy Cross Mts. and Upper Silesia, and P. muensteri from the Holy Cross Mts., Ciechocinek and the Middle Jurassic flora of Grojec (for references see Introduction) are so badly preserved that it is impossible to revise them, and some of them (Upper Silesia) are probably lost. We decided to retain these specimens with their original identification.

The morphology of spores found adhered to the thin pieces of cuticle in the macerated sporangia represent typical trilete, triangular forms with a smooth exine and are mainly known from the ferns of Cyatheaceae, Dipteridaceae, Dicksoniaceae, Matoniaceae and Gleicheniaceae (Balme, 1995). Such kind of spores having thickenings or folds more or less paralleling the leasural radii, are most similar to fossil (of the Late Triassic to Early Cretaceous) and extant matoniaceous spores described by Van Konijnenburg-van Cittert (1993) and Van Konijnenburg-van Cittert and Kurmann (1994), but they also resemble fossil Dipteridaceae spores of Dictyophyllum rugosum (Couper, 1958; Balme, 1995). Van Konijnenburg-van Cittert (1993) and Van Konijnenburg-van Cittert and Kurmann (1994) described and illustrated in situ spores from Matonia braunii based on material from Yorkshire (Middle Jurassic) and Greenland (Early Jurassic) as well as from re-examined slides mentioned by Harris (1931, 1980). Van Konijnenburg-van Cittert (1993) described Matonia braunii spores as valvate, with apices usually slightly thickened. This thickening is not visible in the spores from Niekłań, probably due to the maturity of these spores. The spores from Niekłań are mature and according to Van Konijnenburg-van Cittert and Kurmann (1994), the apical thickenings in matoniaceous spores are much more pronounced in immature spores. The in situ spores from Matonia braunii described here are also slightly smaller (36-46 $\mu \mathrm{m}$ against 43-55 $\mu \mathrm{m}$ ) than those described by Van Konijnenburg-van Cittert (1993) and Van Konijnenburg-van Cittert and Kurmann (1994), but morphologically very similar.

In Poland in situ fossils spores of Matoniaceae have only been described to date by Reymanówna (1963) from Phlebopteris angustiloba specimens found in Grojec near Kraków (southern Poland).

Triangular, smooth, trilete fossil spores in dispersed state can be attributed to several genera: Matonisporites Couper, 1958; Concavisporites Pflug in Thomson and Pflug, 1953; Dictyophyllidites Couper, 1958; Deltoidospora Miner, 1935; Cyathidites Couper, 1953; Phlebopterisporites Juhász, 1979 and Phanerosorisporites Juhász, 1979 (Miner, 1935; Couper, 1953, 1958; Thomson and Pflug, 1953; Juhász, 1979; Litwin, 1985; Van Konijnenburg-van Cittert, 1993; Balme, 1995). Dispersed spores described as Deltoidospora and Cyathidites are triangular and trilete with a smooth exine, but only sometimes have delicate thickenings near the trilete mark and do not have elevated and labrate commissures. Dispersed Matonisporites, Phlebopterisporites and Phanerosorisporites usually have a thick exine. Dispersed Concavisporites and Dictyophyllidites, especially Dictyophyllidites mortoni (de Jersey, 1959) Playford et Dettmann, 1965, possess a trilete mark with elevated and labrate commissures, thickenings subparallel to the trilete mark and a relatively thin exine, so they are most similar to the in situ spores from the Niekłań fern.

Triangular, trilete dispersed spores with a smooth exine do not have clear systematics because of various opinions on the synonymy of these spore species. Lund (1977) placed Leio- 

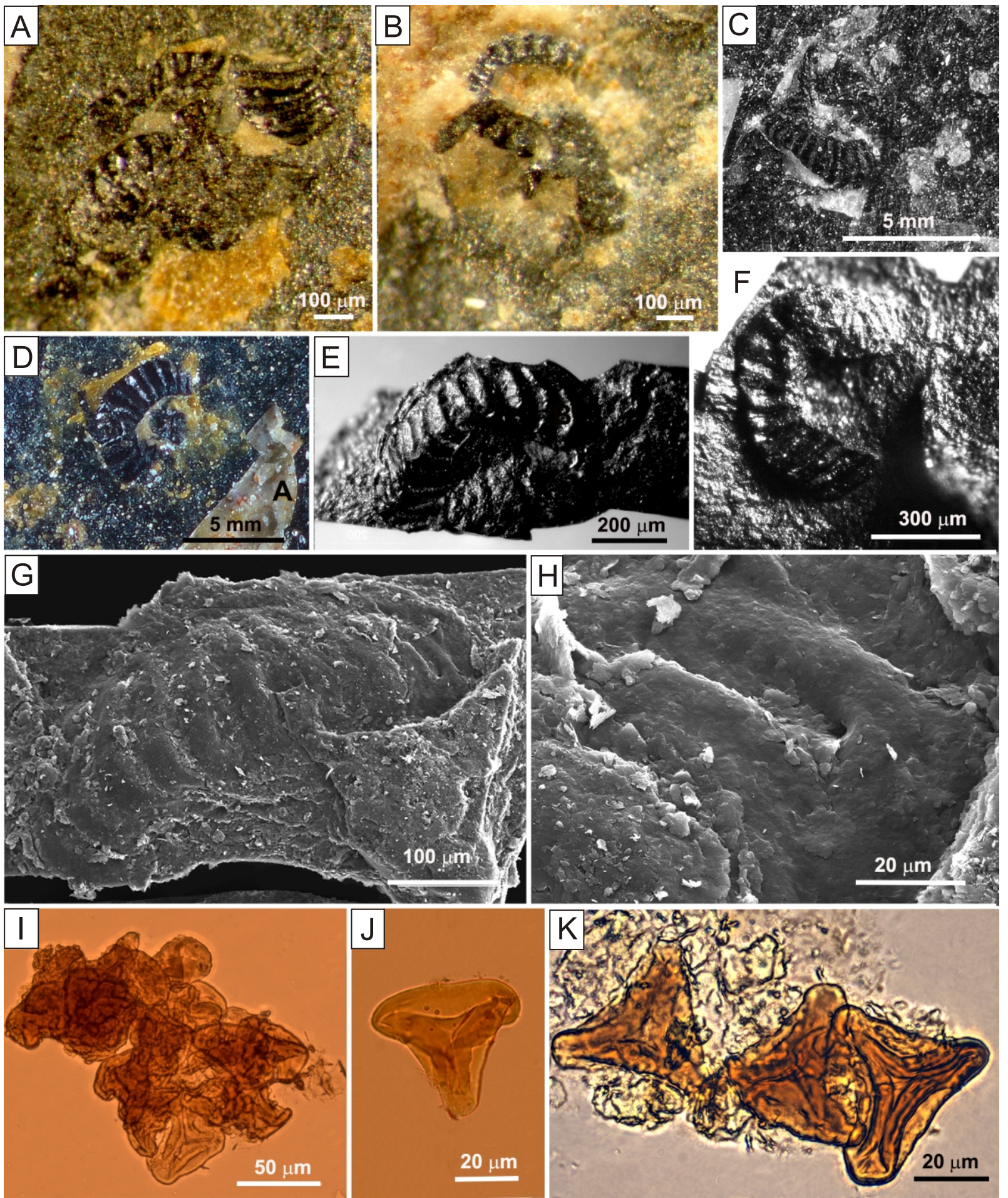

Fig. 5. Matonia braunii (Göppert) Harris

A, B - specimen Muz. Geol. PIG 80.VI.150A, sori, only annuli preserved after sporangia decomposition; C-F - specimen 80.VI.150A, sori with only one annulus preserved; $\mathbf{G}$ - specimen 80.IV.150A, annulus, SEM picture; $\mathbf{H}$ - detail of annulus from Figure 5G, visible thickened anticlinal walls forming ribs, SEM picture; I - cluster of about 20 spores; J, $\mathbf{K}$ - spores in situ in LM, proximal view showing trilete mark and kyrtome (interradial and apical thickenings)

triletes Naumova, 1939, Cyathidites, Concavisporites and Dictyophyllidites in Deltoidospora and treated Dictyophyllidites mortoni (de Jersey, 1959) Playford et Dettmann, 1965 (= Leiotriletes mortoni de Jersey, 1959) as a synonym of Deltoidospora toralis (Leschik, 1955) Lund, 1977 (Leschik, 1955; de Jersey, 1959; Playford and Dettmann, 1965). Jansonius and Hills (1976) and Litwin (1985) treated these genera as distinct.
Dispersed spores "similar" to the spores of Matoniaceae, e.g. Dictyophyllidites mortoni (de Jersey, 1959) Playford et Dettmann, 1965 (= spores described as Clathropteris obovata var. magna Turatanova-Ketova in papers of Rogalska, 1954, 1956), Matonisporites equiexinus Couper, 1958, Matonisporites phlebopteroides Couper, 1958, Matonisporites sp. and spores cf. Matonia sp. or Matoniaceae in Rogalska, 1976 and 
Mamczar, 1986), have been described from Rhaetian and Lower Jurassic sediments of western Poland (Orłowska-Zwolińska, 1983), Pomerania (Pieńkowski et al., 2012), and Lower Jurassic sediments of the Holy Cross Mts. region (Rogalska, 1976; Ziaja, 2006), including the Mroczków-Rozwady area (Rogalska, 1956). Besides the Rhaetian-Lower Jurassic deposits, these spores were also found in Middle Jurassic sediments of the Holy Cross Mts. region (Rogalska, 1976), and Upper Jurassic and Lower Cretaceous sediments of the Kuyavian region (Mamczar, 1986).

\section{PALAEOENVIRONMENT AND PALAEOECOLOGY OF MATONIA BRAUNII}

The environmental background of Matonia braunii from the Niekłań borehole can be convincingly interpreted as a floodplain-backswamp environment located at the transition between floodplain (crevasse splay-delta) and lacustrine-backswamp zones. Specimens are preserved in a laminated claystone. The fern was found in the upper part of the Zagaje Formation, below the marine transgression surface. The transgression surface marks the bottom of the next parasequence and Skłoby Formation (Fig. 1). The approaching transgression significantly influenced sedimentary processes, raising the water table and at the same time limiting delivery of clastic sediments, which enabled the accumulation of peat and coaly deposits. The plant probably grew near the shore of a small floodplain lake and fossilized in mud delivered by the flooding of a nearby river.

Some conclusions about palaeoclimate can be delivered by clay mineralogy. The clay minerals in the Niekłań profile are largely detrital and show a generally insignificant diagenetic overprint (Brański, 2009, 2014; Pieńkowski et al., 2014) due to moderate burial and the fairly closed hydrologic system. There is no distinct and systematic evolution of clay-mineral assemblages from top to bottom of the studied boreholes that are indicative of burial diagenesis. In the Niekłań profile and the whole Zagaje Formation, kaolinite generally predominates (with an average content of $49-54 \%$ ) over illite (average content of $33-46 \%$, respectively). Chlorite is subsidiary to a significant extent, and smectite is almost absent. Clay mineral data are reflected in the major element geochemistry and in the values of alteration indices, which are high in the Upper Rhaetian and Lower Hettangian strata. The Chemical Index of Alternation (CIA) ranges from 79 to 96 , but in the vast majority of cases it exceeds 85, and these are due to residual clays (Nesbitt and Young, 1982). The CIA shows a loss of $\mathrm{Ca}^{2+}, \mathrm{K}^{+}$and $\mathrm{Na}^{+}$in relation to $\mathrm{Al}^{2+}$ (Nesbitt and Young, 1982: caption of fig. 2). Fluctuations in both the kaolinite/illite ratio and $\mathrm{CIA}$ are very useful for recognizing climate fluctuations (Brański, 2009, 2014; Pieńkowski et al., 2014). Interestingly, at the interval of the occurrence of the fern $(41.8 \mathrm{~m})$, these indices are characterized by a slightly lower kaolinite/illite ratio (one of three minima within the Zagaje Formation in Niekłań), and the lower CIA (P. Brański, pers. comm., 2013) points to somewhat cooler (precisely, less hot) conditions, while the humidity remained very high. The habitat of Matonia braunii can be characterized as wet and warm (but not hot) climate conditions, corresponding with the generally similar environmental requirements of other Mesozoic ferns (Van Konijnenburg-van Cittert, 2002; Wang, 2002).

In Poland, Jurassic ferns are usually associated with alluvial and lacustrine depositional systems in continental settings (Odrowąż, Huta OP-1 and Gromadzice - Holy Cross Mts.) or with deltaic depositional systems in coastal settings (Szewna, Dźwiertnia, Chlewiska, Jędrzejowice, Chmielów - Holy Cross Mts.; Siewierz and Zawiercie - Upper Silesia) (Pieńkowski, 2004; Barbacka et al., 2010, 2014a). This accords with general tendencies in fern environmental preferences, since in the Early Jurassic of Europe, ferns were most diverse in alluvial and deltaic environments (Barbacka et al., 2014b).

\section{CONCLUSIONS}

- Matonia braunii (Göppert) Harris has been reported for the first time from Poland, from a borehole in a new locality, Niekłań. This material for the first time fully confirms Harris' suggestions about the taxonomy of this species.

- Triangular, smooth, trilete, kyrtomate spores isolated from sporangia are most similar to in situ spores obtained from different fern species of Matoniaceae and dispersed Dictyophyllidites mortoni (de Jersey) Playford et Dettmann.

- Thanks to a detailed sedimentological study of the borehole in Niekłań, the environmental requirements of this species were precisely defined for the first time. The fern occupied high moisture areas of the lake shore.

- Slightly lower kaolinite/illite ratio in the interval of the occurrence of the fern points to somewhat cooler (precisely, less hot) conditions, while the humidity remained very high.

- The fern's habitat was proposed to be wet and warm (but not hot).

Acknowledgements. The authors express their thanks to K. Bóka for taking SEM pictures of the sporangia, A. Sojka for her drawings and M. Szewczyk for his excellent macro photographs. We are also thankful to B. Bomfleur for his willingness to discuss the morphology of sori and annuli. We are thankful to M. Hodbod for information on palynomorph assemblage in the Niekłań core and to R. Pointer and P. Palmer for linguistic corrections. The authors gratefully acknowledge comments by the Reviewers, E. Kustatscher and J.H.A. van Konijnenburg-van Cittert, who contributed to the manuscript improvement during the peer review process. The study was supported by a grant financed from the resources of the Polish National Science Centre, granted on the basis of decision no. DEC-2012/06/M/ST10/00478 and by the W. Szafer Institute of Botany, Polish Academy of Sciences through its statutory funds. GP research was financially supported by the Institute of Botany at the Jagiellonian University (K/ZDS/005396, K/ZDS/006302, K/ZDS/006305). 


\section{REFERENCES}

Appert, O., 1973. Die Pteridophyten aus dem Oberen Jura des Manamana in Südwest-Madagaskar. Schweizerische Paläontologische Abhandlungen, 94: 1-62.

Arndorff, L., 1993. Lateral relations of deltaic palaeosols from the Lower Jurassic Rrnne Formation on the island of Bornholm, Denmark. Palaeogeography, Palaeoclimatology, Palaeoecology, 100: 235-250.

Arnold, C.A., 1956. Fossil ferns of the Matoniaceae from North America. Journal of the Palaeontological Society of India, 1 : 118-121.

Ash, S.R., 1969. Ferns from the Chinle Formation (Upper Triassic) in the Fort Wingate area, New Mexico. U.S. Geological Survey Professional Paper, 613-D: 1-52.

Ash, S.R., 1972. Piazopteris branneri from the Lower Jurassic, Egypt. Review of Palaeobotany and Palynology, 13: 147-154.

Ash, S.R., 1991. A new Jurassic Phlebopteris (Plantae, Filicales) from the Wallowa Terrane in the Snake River Canyon, Oregon and Idaho. Journal of Paleontology, 65: 322-329.

Ash, S., 2001. The fossil ferns of Petrified Forest National Park, Arizona, and their paleoclimatological implications. In: Proceedings of the 6th Fossil Resource Conference (ed. V.L. Santucci) 3-10. Geologic Resources Division Technical Report, NPS/NRGRD/GRDTR-01/01.

Ash, S., Litwin, R.J., Traverse, A., 1982. The Upper Triassic fern Phlebopteris smithii (Daugherty) Arnold and its spores. Palynology, 6: 203-219.

Aslan, A., Autin, W.J., 1999. Evolution of the Holocene Mississippi River floodplain, Ferriday, Louisiana: insights on the origin of fine-grained floodplains. Journal of Sedimentary Research, 69 800-815.

Balme, B.E., 1995. Fossil in situ spores and pollen grains: an annnoted catalogue. Review of Palaeobotany and Palynology, 87: 81-323.

Barbacka, M., 2011. Biodiversity and the reconstruction of Early Jurassic flora from the Mecsek Mountains (southern Hungary). Acta Palaeobotanica, 51: 127-179.

Barbacka, M., Ziaja, J., Wcisło-Luraniec, E., Reymanówna, M., 2007. Hirmeriella muensteri (Schenk) Jung from Odrowąż (Poland), with female and male cones, and in situ Classopollis pollen grains. Acta Palaeobotanica, 47: 339-357.

Barbacka, M., Ziaja, J., Wcisło-Luraniec, E., 2010. Taxonomy and palaeoecology of the Early Jurassic macroflora from Odrowąz, central Poland. Acta Geologica Polonica, 60: 373-392.

Barbacka, M., Pacyna, G., Feldman-Olszewska, A., Ziaja, J., Bodor, E.R., 2014a. Triassic-Jurassic flora of Poland; floristical support of climatic changes. Acta Geologica Polonica, 64 281-308.

Barbacka, M., Bodor, E.R., Jarzynka, A., Kustatscher, E., Pacyna, G., Popa, M.E., Scanu, G.G., Thévenard, F., Ziaja, J., 2014b. European Jurassic floras: statistics and paleoenvironmental proxies. Acta Palaeobotanica, 54: 173-195.

Barbacka, M., Popa, M.E., Mitka, J., Bodor, E., Pacyna, G., 2015 Relationships between ecosystems and plant assemblages as responses to environmental conditions in the Lower Jurassic of Hungary and Romania. Acta Palaeobotanica, 55: 3-17.

Bartiromo, A., Barone Lumaga, M.R., Bravi, S., 2006. First finding of a fossil fern (Matoniaceae) in the paleontological site of Pietraroja (Benevento, Southern Italy). Bollettino della Società Paleontologica Italiana, 46: 29-34.

Berry, E.W., 1919. A new Matonidium from Colorado, with remarks on the distribution of the Matoniaceae. Bulletin of the Torrey Botanical Club, 46: 285-294.

Bohacs, K., Suter, J.R., 1997. Sequence stratigraphic distribution of coaly rocks: fundamental controls and paralic examples. AAPG Bulletin, 81: 1612-1639.

Brański, P., 2009. Influence of palaeoclimate conditions and greenhouse effect on the Hettangian clay mineral assemblages (Holy
Cross Mts. area, Polish Basin). Geological Quarterly, 53 (3): 363-368.

Brański, P., 2014. Climatic disaster at the Triassic-Jurassic boundary - a clay minerals and major elements record from the Polish Basin. Geological Quarterly, 58 (2): 291-310.

Camus, J.M., 1990. Marattiaceae. In: The Families and Genera of Vascular Plants. Vol. I. Pteridophytes and Gymnosperms (eds. K.U. Kramer and P.S. Green): 174-180. Springer, Berlin, Heidelberg.

Christenhusz, M.J.M., Chase, M.W., 2014. Trends and concepts in fern classification. Annals of Botany, 113: 571-594.

Cleal, C.J., 1993. Pteridophyta. In: The Fossil Record 2 (ed. M.J. Benton): 779-794. Chapman and Hall, London.

Couper, R.A., 1953. Upper Mesozoic and Cainozoic spores and polIen grains from New Zealand. New Zealand Geological Survey. Paleontological Bulletin, 22: 1-77.

Couper, R.A., 1958. British Mesozoic microspores and pollen grains. A systematic and stratigraphic study. Palaeontographica Abt. B, 103: 75-179.

Czier, Z., 1994. On a new record of Selenocarpus muensterianus (Presl) Schenk from the Fireclay Formation of Suncuius (Romania) and the lower Liassic age of the flora. Review of Palaeobotany and Palynology, 82: 351-363.

De Jersey, N.J., 1959. Jurassic spores and pollen grains from the Rosewood Coalfield. Queensland Government Mining Journal, 60: 346-366.

Gierliński, G., Pieńkowski, G., 1999. Dinosaur track assemblages from Hettangian of Poland. Geological Quarterly, 43 (3): 329-346.

Gierliński, G., Niedźwiedzki, G., Pieńkowski, G., 2001. Gigantic footprint of a theropod dinosaur in the Early Jurassic of Poland. Acta Palaeontologica Polonica, 46: 441-446.

Gierliński, G., Pieńkowski, G., Niedźwiedzki, G., 2004. Tetrapod track assemblage in the Hettangian of Sołtyków, Poland, and its paleoenvironmental background. Ichnos, 11: 195-213.

Givulescu, R., Popa, M., 1998. Aninopteris formosa Givulescu et Popa, gen. et sp. nov., a new Liassic matoniaceous genus and species from Anina, Banat, Romania. Review of Palaeobotany and Palynology, 104: 51-66.

Göppert, H.R., 1841. Les Genres des Plantes Fossiles. Lief. 1-2. Verlag von Henry und Cohen, Bonn.

Harris, T.M., 1931. The Fossil Flora of Scoresby Sound East Greenland. Part 1: Cryptogams (Exclusive of Lycopodiales). Meddelelser om Grønland, 85: 1-102.

Harris, T.M., 1961. The Yorkshire Jurassic Flora I: Thallophyta Pteridophyta. Trustees of the British Museum (Natural History), London.

Harris, T.M., 1980. The Yorkshire Jurassic fern Phlebopteris braunii (Goeppert) and its reference to Matonia R. Br. Bulletin of the British Museum (Natural History) Geology Series, 33: 295-311.

Hirmer, M., Hörhammer, L., 1936. Morphologie, Systematik und geographische Verbreitung der fossilen und rezenten Matoniaceen. Palaeontographica Abt. B, 81: 1-70.

Iwasuki, K.I., 1990. Hymenophyllaceae. In: The Families and Genera of Vascular Plants. Vol. I. Pteridophytes and Gymnosperms (eds. K.U. Kramer and P.S. Green): 157-162. Springer, Berlin, Heidelberg.

Jansonius, J., Hills, L.V., 1976. Genera File of Fossil Spores and Pollen. Special Publication, Department of Geology University of Calgary, Canada.

Jarzynka, A., 2012. Środkowojurajska flora glinek grojeckich taksonomia i paleoekologia (in Polish). Ph.D. theses. Archives W. Szafer Institute of Botany, Polish Academy of Sciences, Kraków.

Juhász, M., 1979. Dispersed Matoniaceae spores from the Hungarian Lower and Middle Cretaceous sediments. Acta Biologica Szegedensis, 25: 33-47. 
Klavins, S.D., Taylor, T.N., Taylor, E.L., 2004. Matoniaceous ferns (Gleicheniales) from the Middle Triassic of Antarctica. Journal of Paleontology, 78: 211-217

Kozur, H.W., Weems, R.E., 2010. The biostratigraphic importance of conchostracans in the continental Triassic of the northern hemisphere. Geological Society Special Publications, 334: 315-417.

Kramer, K.U., 1990. Matoniaceae. In: The Families and Genera of Vascular Plants. Vol. I. Pteridophytes and Gymnosperms (eds. K.U. Kramer and P.S. Green): 183-185. Springer, Berlin, Heidelberg.

Kvaček, J., Dašková, J., 2010. Konijnenburgia, a new genus of the fern family Matoniaceae. Review of Palaeobotany and Palynology, 158: 308-318.

Leschik, G., 1955. Die Keuperflora von Neuewelt bei Basel. II. Die Iso- und Mikrosporen. Schweizerische Paläontologische Abhandlungen, 72: 1-70.

Litwin, R.J., 1985. Fertile organs and in situ spores of ferns from the Late Triassic Chinle formation of Arizona and New Mexico, with discussion of the associated dispersed spores. Review of Palaeobotany and Palynology, 44: 101-146.

Lund, J.J., 1977. Rhaetic to Lower Liassic palynology of the onshore south-eastern North Sea Basin. Danmarks Geologiske Undersrgelse II Rk., 109: 1-129.

Lundblad, A.B., 1950. Studies in the Rhaeto-Liassic floras of Sweden. I. Pteridophyta, Pteridospermae and Cycadophyta from the mining district of NW Scania. Kungliga Svenska Vetenskapsakademiens Handlingar, Ser., 4: 1-82.

Makarewiczówna, A., 1928. Etude sur la flore fossile du lias inférieur des environs d'Ostrowiec (in Polish with French summary). Prace Towarzystwa Przyjaciół Nauk w Wilnie, Wydział Nauk Matematycznych i Przyrodniczych, Prace Zakładu Geologicznego Uniwersytetu St. Batorego w Wilnie, 4: 1-49.

Mamczar, J., 1986. Palynostratigraphy of the Uppermost Jurassic and Lower Cretaceous in the Polish Lowlands (in Polish with English summary). Prace Instytutu Geologicznego, 116: 1-53.

McCabe, P.J., 1984. Depositional environments of coal and coal-bearing strata. IAS Special Paper, 7: 13-42.

Miner, E.L., 1935. Palaeobotanical examinations of Cretaceous and Tertiary coals: II. Cretaceous and Tertiary coals from Montana. American Midland Naturalist, 16: 616-625.

Mirzaie Ataabadi, M., Djafarian, M., Mohammadalizadeh, J., 2005. Occurrence of Aninopteris (Matoniaceae) from the Middle Jurassic of East central Iran. Palaeobotanist, 54: 99-106.

Nagalingum, N.S., Cantrill, D.J., 2006. Early Cretaceous Gleicheniaceae and Matoniaceae (Gleicheniales) from Alexander Island, Antarctica. Review of Palaeobotany and Palynology, 138 : 73-93.

Naugolnykh, S.V., Pronin, A.P., 2015. A new matoniaceous fern from the Upper Triassic of the Caspian Depression in the context of florogenetic processes of transition from the Paleozoic to Mesozoic. Paleontological Journal, 49: 326-336.

Nesbitt, H.W., Young, G.M., 1982. Early Proterozoic climates and plate motions inferred from major element chemistry of lutites. Nature, 299: 715-717.

Niedźwiedzki, G., 2011. Dinosaur tracks from the Early Jurassic ecosystem of Sołtyków, Holy Cross Mountains (in Polish with English summary). Biuletyn Państwowego Instytutu Geologicznego, 447: 49-98.

Orłowska-Zwolińska, T., 1983. Palynostratigraphy of the upper part of Triassic epicontinental sediments in Poland (in Polish with English summary). Prace Instytutu Geologicznego, 104: $1-89$.

Pacyna, G., 2013. Critical review of research on the Lower Jurassic flora of Poland. Acta Palaeobotanica, 53: 141-163.

Pieńkowski, G., 2004. The epicontinental Lower Jurassic of Poland. Polish Geological Institute Special Papers, 12: 1-122.

Pieńkowski, G., Gierliński, G., 1987. New finds of dinosaur footprints in Liassic of the Holy Cross Mountains and its palaeoenvironmental background. Przegląd Geologiczny, 35: 199-205.

Pieńkowski, G., Niedźwiedzki, G., Waksmundzka, M., 2012. Sedymentological, palynological and geochemical studies of the terrestrial Triassic-Jurassic boundary in northwestern Poland. Geological Magazine, 149: 308-332.

Pieńkowski, G., Niedźwiedzki, G., Brański, P., 2014. Climatic reversals related to the Central Atlantic magmatic province caused the end-Triassic biotic crisis - evidence from continental strata in Poland. GSA Special Paper, 505: 263-286.

Playford, G., Dettmann, M.E., 1965. Rhaeto-Liassic plant microfossils from the Leigh Creek Coal Measures, South Australia. Senckenbergiana Lethaea, 46: 127-181.

Popa, M., 1997. Liassic ferns from the Steierdorf Formation, Anina, Romania. Mededelinger Nederlands Instituut voor Toegepaste Geowetenschappen TNO, 58: 139-147

PresI, K.B., 1848. Die Gefässbündel im stipes der farrn. Abhandlungen der Königlichen Böhmischen Gesellschaft der Wissenschaften, 5: 307-356.

Raciborski, M., 1891. Flora retycka północnego stoku Gór Świętokrzyskich (in Polish). Rozprawy Wydziału matematyczno-przyrodniczego Akademii Umiejętności w Krakowie, 23: 292-326.

Raciborski, M., 1892. Przyczynek do flory retyckiej Polski (in Polish). Rozprawy Wydziału matematyczno-przyrodniczego Akademii Umiejętności w Krakowie, 22: 345-360.

Raciborski, M., 1894. Flora kopalna ogniotrwałych glinek krakowskich. Część I. Rodniowce (Archaegoniatae) (in Polish). Pamiętnik matematyczno-przyrodniczy Akademii Umiejętności, 18: $1-101$.

Reymanówna, M., 1963. The Jurassic flora from Grojec near Cracow in Poland. Part I. Acta Palaeobotanica, 4: 9-48.

Reymanówna, M., 1992. Two conifers from the Liassic flora of Odrowąż in Poland. In: Palaeovegetational development in Europe and regions relevant to its palaeofloristic evolution (ed. J. Kovar-Eder): 307-311. Proceedings Pan-European Palaeobotanical Conference. Museum of Natural History, Vienna.

Rogalska, M., 1954. Spore and pollen analysis of the Liassic coal of Blanowice in Upper Silesia (in Polish with English summary.) Biuletyn Instytutu Geologicznego, 89: 1-46.

Rogalska, M., 1956. Spore and pollen analysis of the Liassic deposits of the Mroczków-Rozwady area in the Opoczno district (in Polish with English summary). Biuletyn Instytutu Geologiczego, 104: 1-89.

Rogalska, M., 1976. Stratigraphy of the Lower and Middle Jurassic in the Polish Lowlands on the basis of spore and pollen analysis (in Polish with English summary). Prace Instytutu Geologicznego, 78: 1-61.

Rothwell, G.W., Stockey, R.A., 2008. Phylogeny and evolution of ferns: a paleontological perspective. In: Biology and Evolution of Ferns and Lycophytes (eds. T.A. Ranker and Ch.H. Haufler): 332-366. Cambridge University Press, Cambridge.

Rushforth, S.R., 1970. Notes on the fern family Matoniaceae from the Western United States. Brigham Young University Geology Studies, 6: 3-34.

Schenk, A., 1867. Die fossile flora der Grenzschichten des Keupers und Lias Frankens. Kreidel's Verlangen, Wiesbaden.

Schmidt, A.R., Dörfelt, H., 2007. Evidence of Cenozoic Matoniaceae from Baltic and Bitterfeld amber. Review of Palaeobotany and Palynology, 144: 145-156.

Schneider, H., Schuettpelz, E., Pryer, K.M., Cranfill, R. Magallón, S., Lupia, R., 2004. Ferns diversified in the shadow of angiosperms. Nature, 428: 553-557.

Schweitzer, H-J., 1978. Die Räto-Jurassischen Floren des Iran und Afganistans. 5. Todites princeps, Thaumatopteris brauniana und Phlebopteris polypodioides. Palaeontographica Abt. B, 168: $17-60$

Schweitzer, H-J., Schweitzer, U., Kirchner, M., Van Konijnenburg-van Cittert, J.H.A., Van der Burgh, J., Ashraf, R.A. 2009. The Rhaeto-Jurassic flora of Iran and Afghanistan. 14. Pterophyta - Leptosporangiatae. Palaeontographica Abt. B, 279: 1-108.

Seward, A.C., 1899. On the structure and affinities of Matonia pectinata, $\mathrm{R}$. Br., with notes on the geological history of the Matonineae. Philosophical Transactions of the Royal Society B: Biological Sciences, 191: 171-209. 
Seward, A.C., 1900. The Jurassic flora I. The Yorkshire coast. Catalogue of the Mesozoic Plants in the Department of Geology, British Museum (Natural History), 3: 1-341.

Skog, J.E., 1988. Reassignment of Aspidium heterophyllum to a new genus in the family Matoniaceae. America Journal of Botany, 75: 1120-1129.

Skog, J.E., 2001. The biogeography of Mesozoic leptosporangiate ferns related to extant ferns. Brittonia, 53: 236-269.

Skog, J.E., Litwin, R.L., 1995. Reexamination of the fossil fern genus Dryopterites Berry based on reproductive characteristics. Review of Palaeobotany and Palynology, 89: 235-256.

Smith, A.R., Pryer, K.M., Schuettpelz, E., Korall, P., Schneider, H., Wolf, P.G., 2006. A classification for extant ferns. Taxon, 55: 705-731.

Taylor, T.N., Taylor, E.L., Krings, M., 2009. Paleobotany: the biology and evolution of fossil plants. Second Edition. Academic Press, Burlington.

Thomson, P.W., Pflug, H., 1953. Pollen und Sporen des Mitteleuropäischen Tertiärs. Palaeontographica Abt. B, 94: 1-138.

Tidwell, W.D., Ash, S.R., 1994. A review of selected Triassic to Early Cretaceous ferns. Journal of Plant Research, 107: 417-442.

Tidwell, W.D., Skog, J.E., 1992. Two new fossil matoniaceous stem genera from Tasmania, Australia. Review of Palaeobotany and Palynology, 70: 263-277.

Tralau, H., 1965. Phlebopteris angustiloba (Presl) Hirmer et Hörhammer (Matoniaceae) from "Olstorp" Shaft, Bjuv, Scania. Botaniska Notiser, 118: 373-376.

Wallich, N., 1830. Plantae Asiaticae Rariores, or, Descriptions and Figures of a Select Number of Unpublished East Indian Plants. Part 1. Treuttel and Würtz, London.
Wang, Y., 2002. Fern ecological implications from the Lower Jurassic in Western Hubei, China. Review of Palaeobotany and Palynology, 119: 125-141.

Wang., Y., Mei, S., 1999. Fertile organs and in situ spores of matoniaceous fern from the Lower Jurassic of West Hubei. Chinese Science Bulletin, 44: 1333-1337.

Wcisło-Luraniec, E., 1992. Flora from Odrowąż in Poland - a typical Lower Liassic European flora. In: Palaeovegetational development in Europe and regions relevant to its palaeofloristic evolution (ed. J. Kovar-Eder): 331-335. Proceedings Pan-European Palaeobotanical Conference. Museum of Natural History, Vienna.

Van Konijnenburg-van Cittert, J.H.A., 1993. A review of the Matoniaceae based on in situ spores. Review of Palaeobotany and Palynology, 78: 235-267.

Van Konijnenburg-van Cittert, J.H.A., 2002. Ecology of some Late Triassic to Early Cretaceous ferns in Eurasia. Review of Palaeobotany and Palynology, 119: 113-124.

Van Konijnenburg-van Cittert, J.H.A., Kurmann, M.H., 1994. Comparative ultrastructure of living and fossil matoniaceous spores. In: Ultrastructure of Fossil Spores and Pollen (eds. M.H. Kurmann and J.A. Doyle): 67-86. Royal Botanic Garden, Kew.

Ziaja, J., 1992. The Lower Liassic microflora from Odrowąż in Poland. In: Palaeovegetational development in Europe and regions relevant to its palaeofloristic evolution (ed. J. Kovar-Eder): 337-340. Proceedings Pan-European Palaeobotanical Conference. Museum of Natural History, Vienna.

Ziaja, J., 2006. Lower Jurassic spores and pollen grains from Odrowąż, Mesozoic margin of the Holy Cross Mountains, Poland. Acta Palaeobotanica, 46: 3-83.

Ziegler, P.A., 1990. Geological Atlas of Western and Central Europe -2 nd edition. Shell Int. Petr. Maatsch. B.V. 